\title{
Managing Cashew Rootstock Grafting Size Through Organic Fertilizers
}

\author{
Rogério Langa \\ Instituto de Amêndoas de Moçambique, IP - Delegação Provincial de Gaza. Av.Samora \\ Machel - Edifício da Ex-UDA, Xai-Xai, Telefax 282-22221
}

Armindo Cambule, Felicidade Jorge

Universidade Eduardo Mondlane, Faculdade de Agronomia e Engenharia Florestal - Av. Julius Nyerere N.1. Fixo:+258 21492177/9. Fax:+258 21492176 - Maputo - Moçambique

\section{Américo Uaciquete, Gabriel Barros, Neid Ali Ferreira}

Instituto de Investigação Agrária de Moçambique, IIAM-Centro Zonal Nordeste. Rua de Corrane, Km 7, Nampula - Moçambique; *Correspondence: amuaciquete@ gmail.com

Received: October 25, 2020

doi:10.5296/jas.v9i3.17693
Accepted: July 13, $2021 \quad$ Published: July 17, 2021

URL: https://doi.org/10.5296/jas.v9i3.17693

\begin{abstract}
Seed born cashew (Anacardium occidentale L) seedlings are planted directly when they are produced from polyclonal orchards. In a common scenario, cashew seedlings are grafted before transplanting. For this purpose, adjusting the size between scions and rootstock is highly important for the success of grafts and it can be achieved through a visual selection of scions. However, when working with large numbers of seedlings physical and visual selection becomes laborious and time consuming for the workers. Therefore, creating uniformity in seedlings size before grafting is crucial. We present experimental results showing the linear regression between the fertilization level and seedling stem size. Two experiments were conducted in Mozambique: One at Nassuruma cashew Research Station, Nampula province, following a Completely Randonmized Block Design (CRBD), seven treatments, ten bags per treatment and five replicates. The treatments consisted of a fertilizer organically composted from cashew nut shells and applied at rates of $0,4,8,16,32,40$ and $48 \%$ of the total amount of soil in each bag. The second experiment was carried out at Chizavane nursery, in Gaza Province, also based on CRBD, in factorial arrangement of 4 and 3 levels of Kelp and Stimu biofertilizers respectively. Two stem size variables, diameter and height, were considered and
\end{abstract}


data collected at 120 days after seedlings emergence in Nampula and 45 days after emergence in Gaza Province. Polynomial or simple regression analysis model for stem diameter and plant height was performed. The stem diameter was linearly described as an increasing equation. The height was also linearly related to fertilizer but following a decreased equation. We concluded that applying appropriate dosage of fertilizer in the soil or on the leaves could adjust the stem size of the rootstock required for grafting and therefore adjust the stem to the size of scions available. The treatments with high level of Kelp, Stimu and cashew compost fertilization resulted in increase of $8,5 \%, 6 \%$ and $16,6 \%$ of diameter respectively. However, the treatments caused a reduction of height at rate of $14,3 \%, 3,2 \%$ and $25,08 \%$ respectively. The stem and scion size adjustment are highly important for increasing the grafting success rate in a cashew nursery.

Keywords: cashew seedling, scion, foliar and soil fertilization

\section{Introduction}

The cashew (Anacardium occidentale, L.) belongs to Anacardeaceae family and it's originated in South America, Central region of Brasil (Dendena and Corsi, 2014). A global data estimate from Ricau (2019) indicates countries with higher productions in the following sequence: Ivory coast (875 000 MT), India (675 000 MT), Vietnam (450 000 MT), Tanzania (295 000 MT), Nigeria (240 000 MT), Guinea Bissau (185 000 MT) and among others Mozambique with only (70 000 MT). The Portuguese sailors were responsible for the cashew initial spread throughout the world (Milheiro and Evarsito, 1994) and thus introduced the crop in Mozambique in the sixteenth century (Martin et al., 1997). Since then, cashew has been cultivated all over the coastal areas of Mozambique (Milheiro and Evaristo, 1994) but yields in general have been less than one metric ton per hectare or just less than $16 \mathrm{kgs}$ per tree (Grobe-Rüschkamp e Seelige, 2010). Such low levels of productivity have been attributed to aging of trees (Frei, 2013) associated to high disease and pests pressure (Low et al., 2001). In response, the government of Mozambique has been acting in integrated cashew management approach which includes planting more seedlings as a key for cashew farms rehabilitation.

Such seedlings quantities require substantial amounts of substrate that can hold nutrients long enough before transplanting. However, this would mean counter facing the effect of irrigations that has been found to significantly reduce nutrients from the substrate (Aguiar et al., 2006) and indeed affects the seedlings quality (Costa et al., 2011 \& Rickli e Peres, 2016) and thus extend the period before grafting and/or transplanting. The problem of nutrient depletion in potted substrates can be overcome through appropriate formulations of organic and inorganic composts (Cavalcanti \& Chaves, 2001). On seedlings, inorganics may have adverse effect on the microflora associated with root (Dixit E., 2011; Mostafa e Abo-Boker, 2010). Upon seedlings transplanting, inorganics fertilizers may also enter the groundwater later and cause environmental impact to other living systems and crops productivity (Roy et al, 2006). Therefore, organics such as bovine manure, sugar cane bagasse (De Lima et al., 2001) or biofertilizers are found to be environmentally healthy despite requiring extra care in handling (Bhardwaj et al., 2014). Moreover, organics have been a joice in modern agriculture 
because they promote and stimulate gradual release of nutrients into the soil (Serrano et al., 2018; Shankarappa et al., 2017). Based on this realization, several studies have explored the use of vermicompost and sugar cane bagasse (De Lima et al., 2001), carbonized rice or coco nut fiber (Correia et al., 2003) and pine burk (Serrano et al., 2016) in cashew seedling production systems. Among organics, biofertilizers are known to be an efficient approach for essential nutrient supplementation that induces rapid growth and plant robustness (Shehata et al., 2003). This is because bio-fertilizers in their composition include calcium and magnesium which are essential components in formulations (Dendena and Corsi, 2014). They have been found to balance the negative effect of irrigation saline water on cashew seedlings (Torres et al., 2014). Additionally, biofertilizers may also contain nitrogen fixing microflora and also microorganisms that play special role in converting and releasing none easily accessible nutrients to the roots (Mostafa \& Abo-Boker, 2010). In rice and maize, biofertilizers have been found to increase yield in 10 and 28\% respectively (Walker, 2009). On cashew seedlings production systems, biofertilizers, have been found to improve total dry matter of plantlets in Brazil as well as in India (Melo Filho et al., 2015 and Shankarappa et al., 2017). Our focus is how to use these fertilizers to ensure seedling size uniformity on time for grafting. Therefore the objective of the current study was to determine the stem size response, diameter and height, to different dosages application of Kelp-p-max biofertilizers (Omnia Nutriology-Bryanston, South Africa) and Stimu-phos (Arysta-LyfeScience, South Africa) and different proportions of organic compost integration formulated from cashew nut shells.

\section{Material and Methods}

\subsection{Trial Sites, Soils and Climate}

One trial was conducted at Nassuruma Cashew Research Center, attached to Agriculture Research Institute of Mozambique, IIAM-North East Zional Centre, located between $14^{\circ} 59^{\prime}$ and 38.162" South and $039^{\circ} 42^{\prime}$ '53.304" East. The area is part of agro-ecological zone R8 characterized by predominance of lixisols, leptosols and arenosols. The average annual temperature is between 24 and $26^{\circ} \mathrm{C}$ and annual rainfall of 800 to $1200 \mathrm{~mm}$ with relative humidity, a characteristic of humid semi-arid, with spots sub-humid and an extensive spots of dry semi-arid (Salustiano et al., 2014).

The second trial was implemented at Chizavane, located between the coordinates 24 54'45.2"S and 33 59'47.3'E, Chidenguele Administrative Post, Mandlakazi District. The area is part of agro-ecological zone R2 with prevalence of arenosol, fluvisols and manangas. The zone is characterized by average annual temperature of 24 to $26^{\circ} \mathrm{C}$, annual rainfall of 800 to $1000 \mathrm{~mm}$ and relative humidity typically humid semi-arid, with some sub-humid spots in the littoral (Salustiano et al., 2014).

\subsection{Trials, Design and Implementation}

A CRBD with seven treatments in five blocks was followed (Peterson, 1994). The treatments (T1 to T7) consisted of amended common top soil with different proportions of cashew nut shell compost at $40 \%$ decomposition level. T1 was not amended and therefore was the experiment negative control while $\mathrm{T} 2$ to $\mathrm{T} 7$ were amended with 4, 8, 16, 32, 40 and $48 \%$ 
(w/w) mixture of compost and the commonly used nursery top soil as described: $\mathrm{T} 1=$ Control; T2 $=96 \%$ Common Soil (CS) $+4 \%$ Cashew Nut Shell (CNS); T3 $=92 \%$ CS $+8 \%$ $\mathrm{CNS} ; \mathrm{T} 4=84 \% \mathrm{CS}+16 \% \mathrm{CNS} ; \mathrm{T} 5=68 \% \mathrm{CS}+32 \% \mathrm{CNS} ; \mathrm{T} 6=60 \% \mathrm{CS}+40 \% \mathrm{CNS} ; \mathrm{e} \mathrm{T} 7$ $=52 \% \mathrm{CS}+48 \% \mathrm{CNS}$. Each experimental plot consisted of 10 polyethylene black pots $(9 \mathrm{x}$ $27 \mathrm{~cm}$ ). The nutritional composition of the cashew nut shell organic compost was analyzed at North East Zonal Center of Mozambique, Agrarian Research Institute (IIAM), Plant and Soil Analysis Laboratory ( $15^{\circ} 08^{\prime} 51.53^{\prime \prime}$ South and 39 $18^{\circ} 82.98$ "East) and the results are presented on Table 1.

Table1: Nutritional composition of cashew nut shell compost at $40 \%$ decomposition.

\begin{tabular}{|c|c|c|c|c|c|c|c|c|c|c|c|}
\hline $\mathrm{pH}\left(\mathrm{H}_{2} \mathrm{O}\right)$ & $\mathrm{CE}$ & $\mathrm{P}$ & $\mathrm{K}$ & $\mathrm{Ca}$ & $\mathrm{Na}$ & $\mathrm{Fe}$ & $\mathrm{Zn}$ & $\mathrm{Cu}$ & $\mathrm{Mn}$ & $\mathrm{N}$ & $\begin{array}{c}\text { M. } \\
\text { O }\end{array}$ \\
\hline--- & {$[\mu \mathrm{S} / \mathrm{cm}]$} & {$[\mathrm{ppm}]$} & \multicolumn{3}{|c|}{$[\mathrm{cmol}(+) / \mathrm{kg}]$} & \multicolumn{4}{|c|}{ [ppm] } & \multicolumn{2}{|c|}{$[\%]$} \\
\hline 6.4 & 13.4 & 618.2 & 26.5 & 13.7 & $\begin{array}{c}5.3 \\
8\end{array}$ & $\begin{array}{c}169 . \\
2\end{array}$ & 182 & $\begin{array}{c}2 . \\
4\end{array}$ & 118 & 0.6 & 24.9 \\
\hline
\end{tabular}

Source: Mozambique, Agriculture Research Institute, IIAM - North East Zonal Center, Plant and Soil Analysis Laboratory, 2017. Where CE is Electric conductivity, P-phosforhus, K-Potassium, Ca-Calcium, Na-Sodium, Fe-Iron, Zn-Zinc, Cu-Copper, Mn-Manganese, N-Nitrogen and M.O - Organic matter.

The trial was conducted during seedling production season from January to April 2018, at almost same size nuts from clone 5.12 PA were visualy inspected for physical damage and then tested for density by submersion in water (Torres et al., 2014; Awodun et al., 2015). All other practices such as watering and pest and disease managament were conducted following the nursery normal procedures.

The experiment at Chizavane, was conducted between September and December, 2018 in a netted insect proof plant house. As the nursery normal practice, the substrate consists of top soil collected from underneath nearby trees up to $20 \mathrm{~cm}$ deep from the surface. This substrate is typically derived from decomposed organic debris. The collected substrate was chemically analyzed before planting and after 90 days of seedling germination per treatment as shown in table 2 .

Both, substrate and cashew seeds were disinfected with copper oxycloride at a ratio of $5 \mathrm{~g} / \mathrm{L}$ of water. The seeds from 12.8 P.A e 5.12 P.A cashew clones with similar size were dipped in to the solution for 24 hours and then placed for pre-germination under a juta bag. Ten days later, uniform germinated seedlings were selected and transferred in to polyethylene bags.

All experimental plots were sprayed with $111 \mathrm{ml}$ of mixture of biofertilizers and water according to the treatment per seedlings, 15 days after germination and repeated in equal intervals up to day 85 after germination. 
The trial was conducted following a CRBD (Gomez and Gomez, 1984) in a two factorial scheme with 4 and 3 levels (Banzatto et al., 2006). That is, two biofertilizers (Kelp-p-max (Kp), from Omnia Nutriology, Bryanston, South Africa and Stimu-phos (St), from Arysta-Lyfe Science, South Africa) with 4 and 3 application doses respectively in a total of 12 treatments as follows: $\mathrm{T} 1=75 \mathrm{ml}$ of Kelp-p-max $(\mathrm{Kp})+0 \mathrm{ml}$ of Stimu-phos $(\mathrm{St}) ; \mathrm{T} 2=150 \mathrm{ml}$ $\mathrm{Kp}+0 \mathrm{ml} \mathrm{St} ; \mathrm{T} 3=215 \mathrm{ml} \mathrm{Kp}+0 \mathrm{ml} \mathrm{St} ; \mathrm{T} 4=0 \mathrm{ml} \mathrm{Kp}+15 \mathrm{ml} \mathrm{St} ; \mathrm{T} 5=0 \mathrm{ml} \mathrm{Kp}+30 \mathrm{ml} \mathrm{St} ; \mathrm{T} 6=75 \mathrm{ml}$ $\mathrm{Kp}+15 \mathrm{ml} \mathrm{St} ; \mathrm{T} 7=75 \mathrm{ml} \mathrm{Kp}+30 \mathrm{ml} \mathrm{St} ; \mathrm{T} 8=150 \mathrm{ml} \mathrm{Kp}+15 \mathrm{ml} \mathrm{St}$; $9=150 \mathrm{ml} \mathrm{Kp}+30 \mathrm{ml} \mathrm{St}$; $\mathrm{T} 10=215 \mathrm{ml} \mathrm{Kp}+15 \mathrm{ml} \mathrm{St} ; \mathrm{T} 11=215 \mathrm{ml} \mathrm{Kp}+30 \mathrm{ml} \mathrm{St} ;$ e T12=0ml K + 0ml St (control).

Table 2. Chemical composition of the substrate, per treatments, used in cashew seedlings production at Chizavane, Chidenguele Administrative Post, Gaza Province - Mozambique, before planting and 90 days after seedling germination

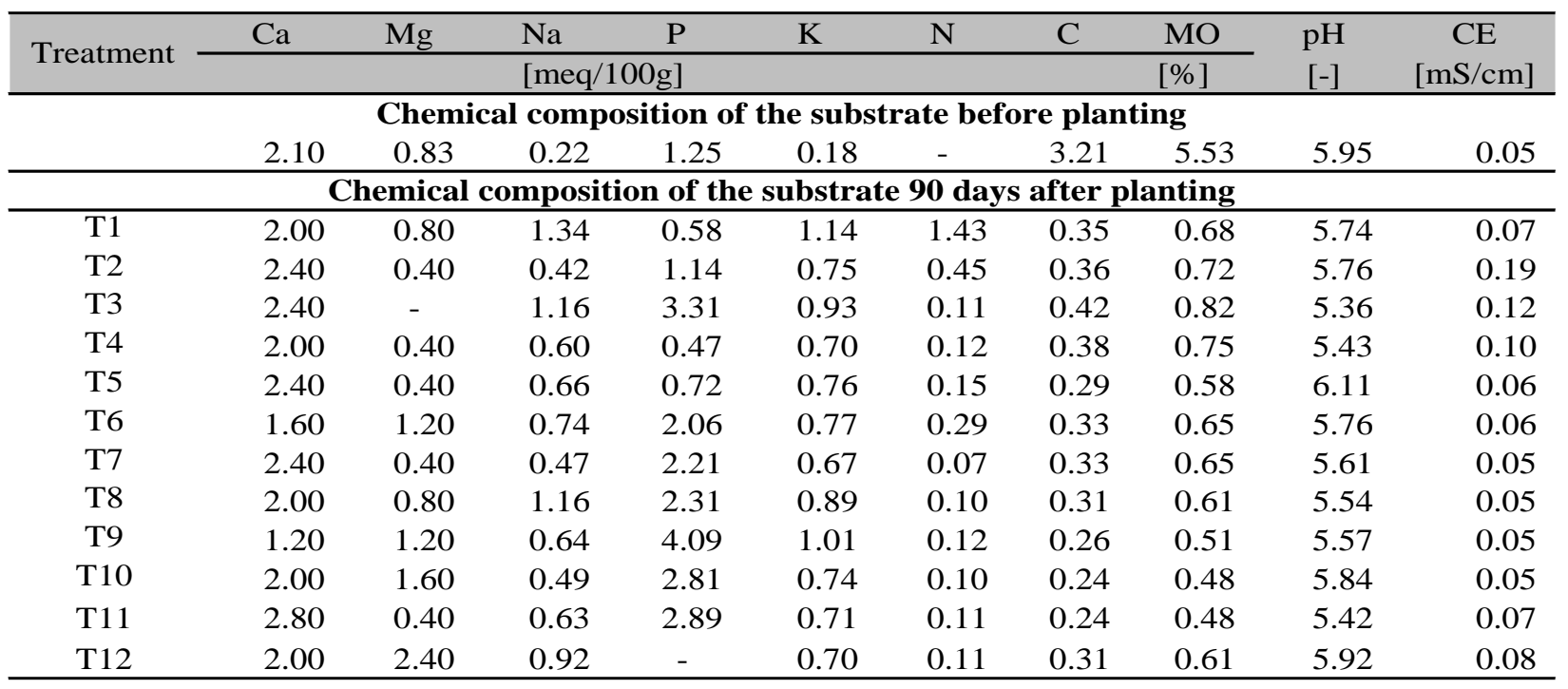

Source: Eduardo Mondlane Faculty of Agricultural Engineering and Forestry - Soil Analysis

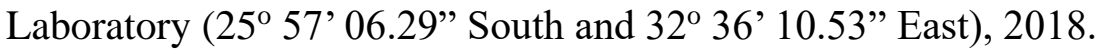

The fertilizers nutrients contents are shown in table 3. Experimental unit consisted of 9 pots suspended on a wood table matrix, constructed from local sticks and chicken net, at $50 \mathrm{~cm}$ high, to hinder the roots from direct contact with the soil.

Table 3. Nutrients contents of the Kelp-p-max and Stimu-phos fertilizers

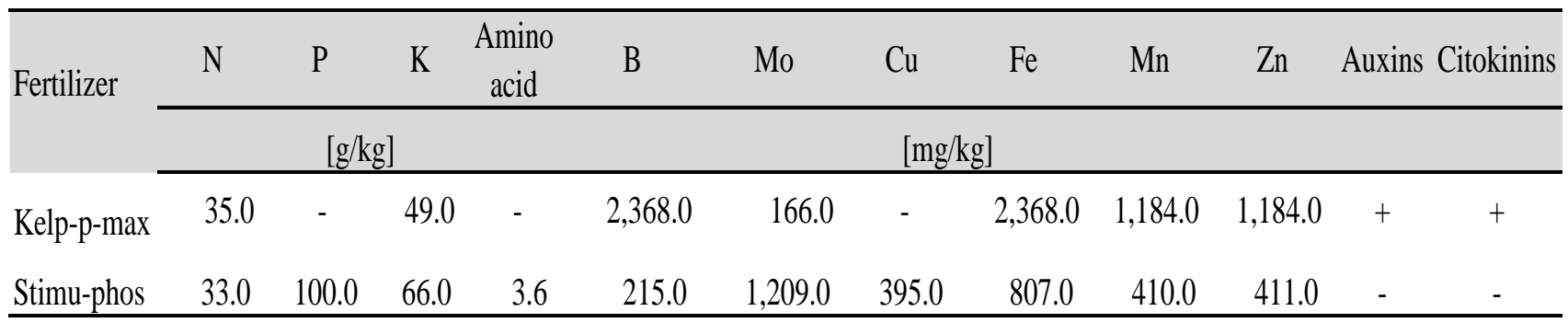

(-) no information; (+) present

Source: Arysta LifeScience, South Africa (Pty) Ltd; and Omnia Nutriology Bryanston, South Africa. 


\subsection{Data Collection}

At Nassuruma, height measurements were taken 120 days after seedling germination. A milimetric roller was used to vertically measure the height from the soil surface to the insertion of the last seedling leaf (Torres et al., 2014). A digital milimetric paquimeter was used to assess the steam diameter at collar height (Gomes et al. 2003; Torres et al., 2014). At Chizavane trial site, seedling diameter and height were measured 45 days after germination following the same procedure described for trial at Nassuruma.

\subsection{Statistical Analysis}

All data were processed in STATA 12 statistical package. From Chizavane factorial trial data were subjected to ANOVA procedure. Verification of ANOVA assumptions was done for error normality and homogeneity through Shapiro Wilk and Breusch Pagan test respectively (Peterson, 1994), transforming original data to $\log _{10}$ (Yij) as data were not following normal distribution. Because no interaction effect was detected between treatment factors, (Kelp*Stimu, $P=0.8192$, for seedling height) as well as for seedling diameter (Kelp* Stimu, $P=0.1086$ ) 45 days after emergence, each biofertilizer (Kelp or Stimu) effect was analyzed separately (Peterson, 1994; Dias and Barros, 2009). For both trials, diameter and height data, collected 45 days after seedling emergence, was subjected to ANOVA regression. Moreover, polynomial regression analysis was performed for Nassuruma data, where soil substrate fertilization was tasted for seven levels of organic fertilizer, similarly with Chizavane data, were foliar biofertlizer Kelp had four concentration levels. However, because biofertilizer Stimu had only 3 levels, for this treatment, only simple regression was used (Dias and Barros, 2009) to analyze seedling height and diameter data from Chizavane trial site.

\section{Results and Discussion}

The results of ANOVA regression for cashew seedling diameter and height response to different fertilizers in both trial (Nassuruma and Chizavane) are shown in Table 4.

Table 4. ANOVA for polynomial and linear regression cashew seedling diameter and height response to different fertilizers on polyethylene pots in Mozambique, 2019

\begin{tabular}{|c|c|c|c|c|c|c|}
\hline Trial Site & $\begin{array}{l}\text { Fertilizer } \\
\text { involved }\end{array}$ & $\begin{array}{c}\text { Seedling } \\
\text { Variable }\end{array}$ & $\begin{array}{l}\text { Regression } \\
\text { model }\end{array}$ & $\mathbf{R}^{2}$ & $\mathbf{R}^{2}$ Adj & MSQ \\
\hline \multirow{7}{*}{$\begin{array}{l}\text { Nassurum } \\
\text { a }\end{array}$} & \multirow{7}{*}{$\begin{array}{l}\text { Cashew } \\
\text { compost }\end{array}$} & \multirow{4}{*}{ Diameter } & $\begin{array}{l}\text { Polynomial } \\
\text { Regression }\end{array}$ & & & $1.67048225^{* *}$ \\
\hline & & & Linear & $\begin{array}{c}88.5220578 \\
1\end{array}$ & $\begin{array}{c}86.2264693 \\
7\end{array}$ & $4.76071627 * *$ \\
\hline & & & Quadratic & $\begin{array}{c}89.2845350 \\
9 \\
93.1842089\end{array}$ & $\begin{array}{c}92680054 \\
86.3684179\end{array}$ & $0.04100595 \mathrm{~ns}$ \\
\hline & & & Cubic & 8 & 7 & $0.20972454 \mathrm{~ns}$ \\
\hline & & \multirow{3}{*}{ Height } & $\begin{array}{l}\text { Polynomial } \\
\text { Regression }\end{array}$ & \multirow{3}{*}{$\begin{array}{r}85.1956956 \\
6 \\
92.5662914 \\
2 \\
92.6119128\end{array}$} & \multirow[b]{2}{*}{$\begin{array}{r}82.2348347 \\
9 \\
88.8494371\end{array}$} & $28.97151761 * *$ \\
\hline & & & Linear & & & $79.95457135 * *$ \\
\hline & & & $\begin{array}{l}\text { Quadratic } \\
\text { Cubic }\end{array}$ & & $\begin{array}{r}4 \\
85.2238256\end{array}$ & $\begin{array}{c}6.91716665 \\
0.04281481 \mathrm{~ns}\end{array}$ \\
\hline
\end{tabular}




\begin{tabular}{|c|c|c|c|c|c|c|}
\hline \multirow{8}{*}{$\begin{array}{c}\text { Chizavan } \\
\text { e }\end{array}$} & \multirow{2}{*}{ Stimu } & Diameter & $\begin{array}{l}\text { Simple } \\
\text { Regression }\end{array}$ & 14.88 & 10.83 & $0.50816^{* *}$ \\
\hline & & Height & $\begin{array}{l}\text { Simple } \\
\text { Regression }\end{array}$ & 0.77 & -3.95 & $0.98568 \mathrm{~ns}$ \\
\hline & \multirow{6}{*}{ Kelp } & \multirow{3}{*}{ Diameter } & $\begin{array}{l}\text { Polynomial } \\
\text { Regression }\end{array}$ & & & $0.26308333 \mathrm{~ns}$ \\
\hline & & & Linear & $\begin{array}{c}91.1297255 \\
7 \\
91.3491722\end{array}$ & $\begin{array}{c}86.6945883 \\
6 \\
74.0475166\end{array}$ & $0.52490266 *$ \\
\hline & & & $\begin{array}{l}\text { Quadratic } \\
\text { Cubic }\end{array}$ & 1 & 4 & $0.001264 \mathrm{~ns}$ \\
\hline & & \multirow[t]{3}{*}{ Height } & $\begin{array}{l}\text { Polynomial } \\
\text { Regression }\end{array}$ & & & $\begin{array}{c}14.06178457 \\
n s\end{array}$ \\
\hline & & & Linear & $\begin{array}{c}68.6380909 \\
3 \\
69.2572446\end{array}$ & 52.9571364 & $27.87214688 *$ \\
\hline & & & $\begin{array}{l}\text { Quadratic } \\
\text { Cubic }\end{array}$ & 7 & 7.77173401 & $0.25142226 \mathrm{~ns}$ \\
\hline
\end{tabular}

* Significant at $5 \%$ level of probability $(\mathrm{p}<0,05) ; * *$ significant at $1 \%$ level of probability $(\mathrm{p}<0,01) ; \mathrm{ns}-$ not significant.

\subsection{Cashew Seedling Stem Size Response to Organic Compost at Nassuruma}

The diameter data were found to follow a reasonable normal distribution ( $\mathrm{X}^{2}$ Probability $=5$. $3 \%$ ) and were acceptably homogeneous (calculated Bartlet's $X^{2}=8.7$ ). Cashew seedlings diameter was significantly $(P>F,<0.0001)$ increased when the substrate was gradually amended with cashew nut shell compost (Figure 1).

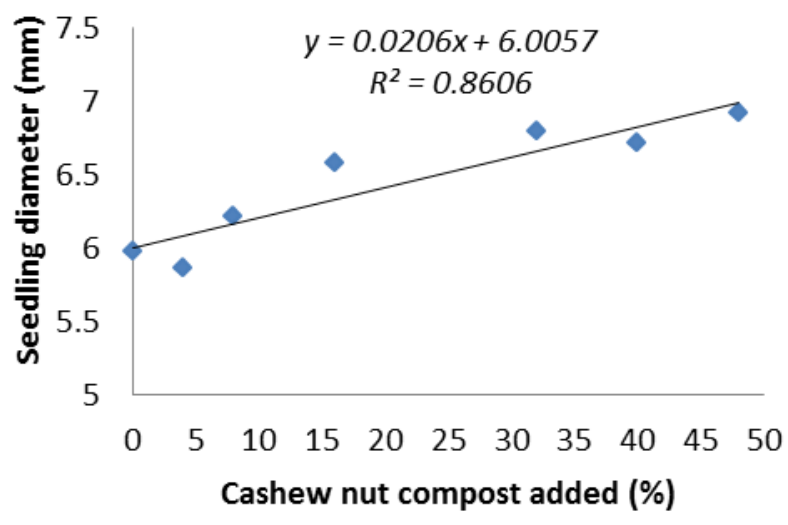




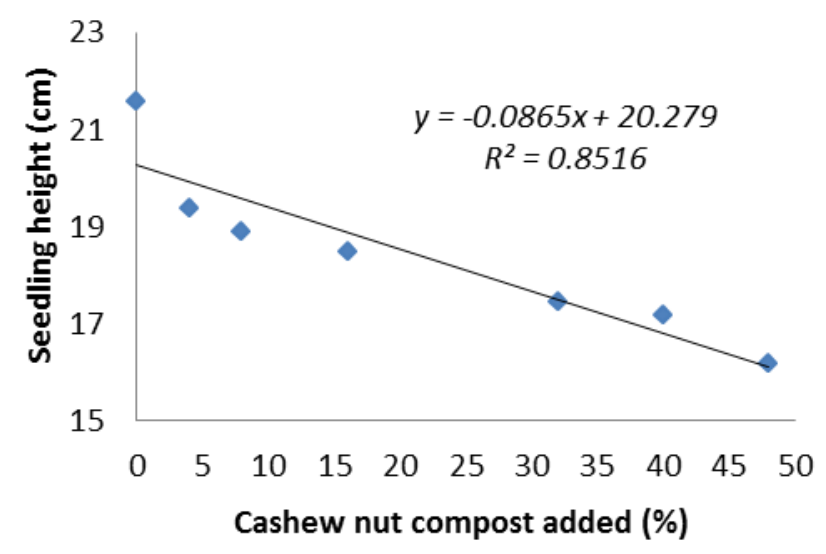

Figure 1. Regression line of cashew seedling diameter (left) and height (right) to different proportions of cashew nut shell compost, 120 days after planting on polyethylene pots, at Nassuruma cashew research center, Mozambique, 2019. The CV values were $7.9 \%$ and $12.4 \%$ for the diameter and height respectively

In fact, seedling diameter increased from $6 \mathrm{~mm}$, with $0 \%$ fertilizer, to almost $7 \mathrm{~mm}$ with $48 \%$ (w/w) substrate amendment. This represents $16.6 \%$ increase in seedlings diamter. Mário et al. (2014), studied the biofertilizers doses effect and substrate volume, also observed an increase of diameter in cashew seedlings. Our results are in agreement with the offered experiment on the organic fertilizer effect. Opposite results were found with Serrano et al., (2018), working with dwarf varieties, 60 days after sowing. They found that formulated slow release substrates HS-citros, Biomix Flores and Germina plant, highly reduced the seedlings diameter (5.4\% and 6.1\% respectively in CCP06 and CCP76 varieties) when compared to conventional NKP fertilizer. The experiment however did not include a zero fertilizer check, neither our trial included a positive conventional control. The two experiments adopted opposite controls, negative in one and positive in another and therefore the results are also contrary. Previous study, Awodun et al., (2015), also revealed an increased effect of stem girth (5.5. to 9.2\%) which can be correlated to seedling diameter, 56 days after planting. The effect range was influenced by the type of organic material used. Similarly, Akanbi et al., (2013) having applied organic materials 6 weeks after seedling sprouting, six months later, found an increased diameter varying between 18.2 and 30.8\%. The key to this positive effect is the choice of appropriate proportion of organic matter to be incorporated, based on the most required plant nutrient, to compensate deficiency in the preplanting soil.

Height data were found to follow a reasonable normal distribution $\left(\mathrm{X}^{2}\right.$ Probability $\left.=1.6 \%\right)$ and were acceptably homogeneous (calculated Bartlet's $X^{2}=7.1$ ). Seedling height was significantly $(P>F=0.0026)$ and proportionally $\left(R^{2}=0.7884\right)$ decreased from $20 \mathrm{~cm}$, with $0 \%$ incorporation of cashew nut shell compost, to about $17 \mathrm{~cm}$ at $48 \%(\mathrm{w} / \mathrm{w})$ amended substrate (Figure 2). This represents 15\% decrease in height, 120 days after planting. In Serrano et al., (2018) experiments, height reduction due to organic compost dose increase from 0 to $8 \mathrm{Kg} / \mathrm{m}^{3}$ was $13.0 \%$, in CCP06 variety, 60 days after planting. Before the two experiments discussed above, the effect of soil amendment with organic material had been experimental examined by Awodun et al., (2015). The authors compared five different 


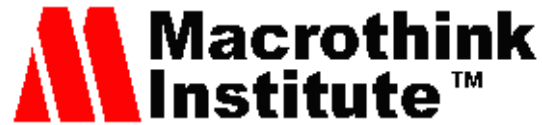

Journal of Agricultural Studies

ISSN 2166-0379

2021, Vol. 9, No. 3

organic composts with a negative control and the impact was an increased height varying from 5.2 to $8.8 \%$, depending on the nature of organic material, 56 days after planting. Akanbi et al., (2013), analyzed the approximate composition of preplanting soil and that of the organic materials to be applied, and then decided on nitrogen as reference, to weigh the organic composts for incorporation. The result was a significant increase in plant height, from 5.99 to $36.9 \%$, six months after application. This practical approach contrary to our findings a gradual increase in chlorosis (Figure 2).

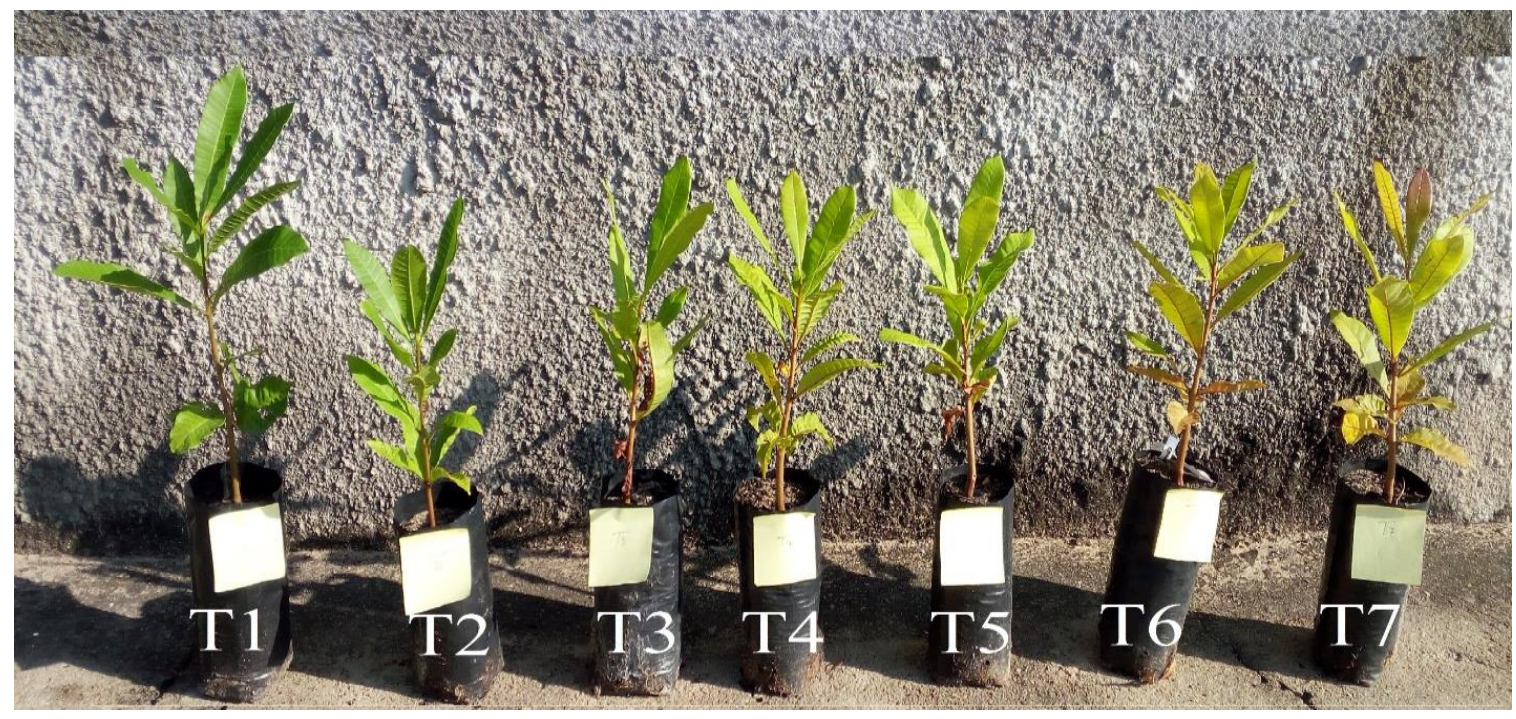

Figure 2. Cashew seedling chlorosis in response to different proportions of cashew nut shell compost, 120 days after planting on polyethylene pots, at Nassuruma cashew research center, Mozambique, 2019

\subsection{Cashew Seedling Stem Size Response to Foliar Biofertizers}

\subsubsection{Kelp Effect}

For both variables, height as well as diameter, the data were reasonably acceptable for a normal distribution and homogeneous variances for analysis.

Cashew seedling diameter response to quarterly foliar applications of Kelp fertilizer was best adjusted to a first degree regression equation (Figure 3) and the observed diameter increase was $5.1 \mathrm{~mm}$ above $4.5 \mathrm{~mm}$ which is considered to be suitable for seedlings to be grafted. 

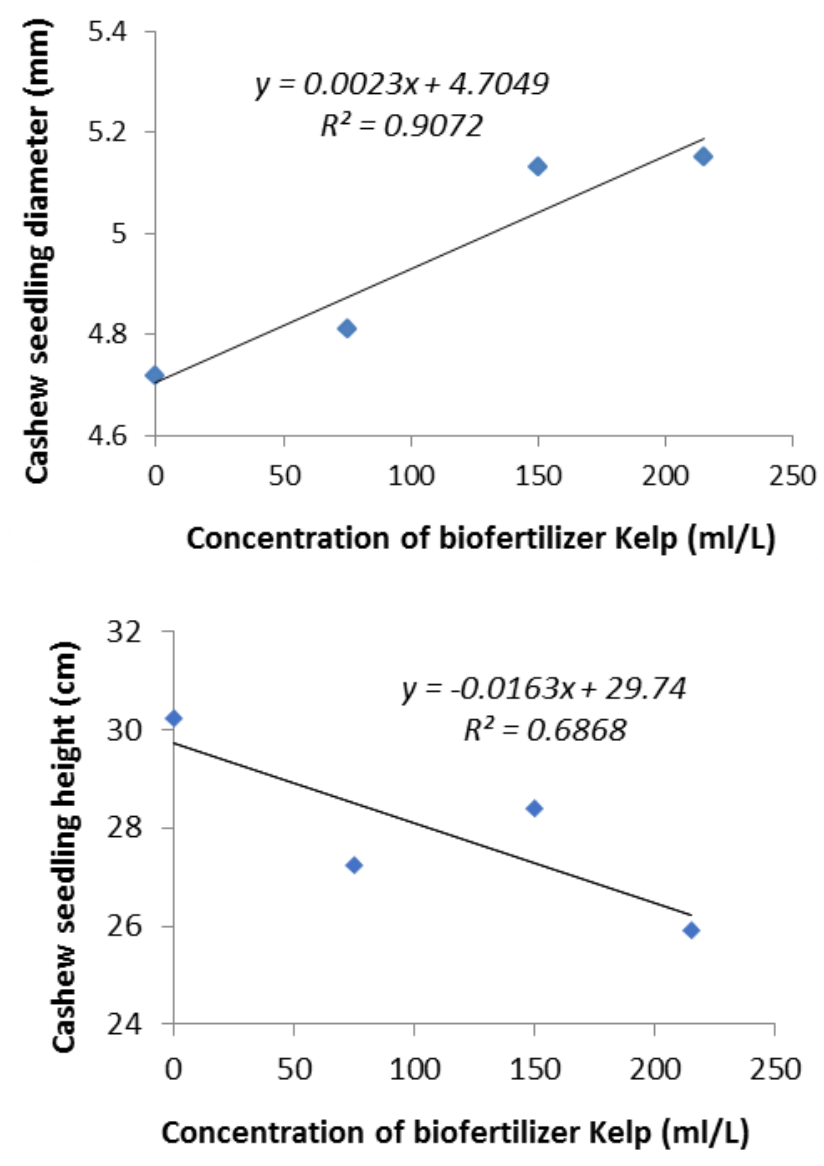

Figure 3. Regression line of cashew seedling diameter (left) and height (right) response to different foliar biofertilizers (Kelp) quarterly applications, 45 days after germination on polyethylene pots, at Chizavane cashew Nursery, Mozambique, 2019; T1= Kp0 ml/L; T2= $\mathrm{Kp} 75 \mathrm{ml} / \mathrm{L} ; \mathrm{T} 3=\mathrm{Kp} 150 \mathrm{ml} / \mathrm{L} ; \mathrm{T} 4=\mathrm{Kp} 215 \mathrm{ml} / \mathrm{L}$

The ANOVA regression was not statistically significant $(P=0.3246)$ despite a relatively low $\mathrm{CV}=2.2 \%$. Nevertheless, the general trend of cashew seedlings diameter was to increase depending on the foliar applications of biofertilizers. Seedling height response was opposite to that of diameter (Figure 3) in which it was observed a decreasing trend.

\subsubsection{Stimu-phos Effect}

The cashew seedling diameter response to quarterly stimu-phos foliar applications was adjusted to simple regression equation and a typical trend of increase was observed from 4.8 to $5.15 \mathrm{~mm}$ (Figure 4). As in Kelp scenario, seedling height tends to respond negatively to the Stimu-phos foliar applications, however simple regression analysis showed no adjustment as proportional shown by $R^{2}$ that was very low (Figure 4 ). 

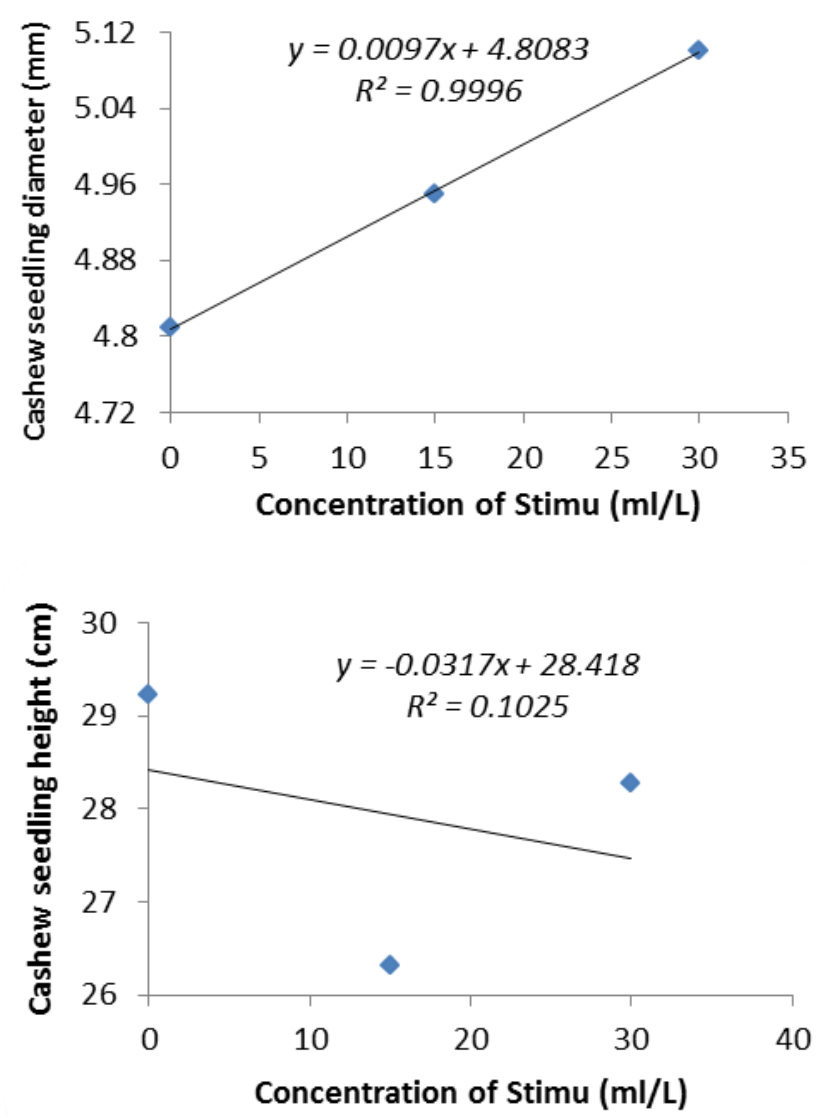

Figure 4: Regression line of cashew seedling diameter (left) and height (right) response to different foliar biofertilizers (Stimu) quarterly applications, 45 days after germination on polyethylene pots, at Chizavane cashew Nursery, Mozambique, 2019; T1=0 m1/L; T2= 15 $\mathrm{ml} / \mathrm{L}$ and $\mathrm{T} 3=30 \mathrm{ml} / \mathrm{L}$.

\section{Discussion}

In two experiments, we focused in understanding the response of cashew seedling size measured as stem diameter and height to applications of different fertilizers proportions. In one case we used organic compost added into the soil and thus nutrients absorbed through the root system, on the other hand we used two formulated biofertilizers for foliar application. The results indicate a similar trend whereby cashew seedling diameter increased due to addition of fertilizer while the height decreased. However, the relatively low number of treatments means that, due to lack of factorial interaction at Chizavane, up to 45 days after seedling emergence, it affected the regression probability for no statistical significance (Dias and Barros, 2009).

Cashew seedling growth vigor can be evaluated in many different ways, for instance the number of leaves over time (Silva et al., 2019), stem diameter and height (Fonseca et al., 2002), dry matter accumulation (Clement and Bovi, 2000), leaf area (Schmildt et al. 2016), root system volume (Rossielo et al., 1995) and quality index (Eloy et al., 2013). In our experiments we focused on cashew seedling diameter because it is associated with survival 
rate in the field (Caldeira et al., 2003), it assures better fixation in definitive soil (Rickli and Peres, 2016) and subsequent better growth of the root system and the plant aerial parts (Eloy et al, 2013).

The stem diameter varied from 5 to $7 \mathrm{~mm}$ and between 3 and $6 \mathrm{~mm}$ at Nassuruma and Chizavane trial respectively. It is worthwhile mentioning that previous work by Serrano and Cavalcanti, (2016) in Brazil, indicated that a size of $4.5 \mathrm{~mm}$ would be suitable for seedlings to be grafted.

Furthermore, soil based organic fertilizers contain growth regulating substances such as auxins that promote secondary roots and improves water and nutrients absorption capacity (Pes and Arenhardt, 2015). Therefore, stem diameter growth in relation to fertilizers applications can be explained by the Nitrogen content (N: 41g/l) and Phosphorous (P: 58g/l) in the formulated Kelp and $\mathrm{N}: 33 \mathrm{~g} / \mathrm{kg}$ and $\mathrm{P}: 100 \mathrm{~g} / \mathrm{kg}$ in biofertilizer Stimu. These nutritional elements are associated with protein synthesis and cell division in plants (Almeida et al., 2012; Rick and Pires, 2016). In sun flour seedlings, for instance, omission of NPK was found to reduce the stem diameter (Prado and Leal, 2006). Except for N, cashew nut shell compost used at Nassuruma trial had high content of $\mathrm{P}$ and $\mathrm{K}$ (Table 1).

Cashew leaves may develop wax on the surface during growth (Sijaona et al., 1999). The wax may hinder nutrient absorption through the leaf laminae (Sijaona et al., 1999) and thus leading to a relatively lower effect of foliar applications of fertilizers on to stem size as observed in these trials. In addition, the use of seeds from two clones at Chizavane trial, may have increased the variability and subsequent high CV's in Gaza experiment in relation to Nassuruma, where only seeds from one cashew clone were used.

The application of organic fertilizers in the soil or on the leaves, for potted cashew seedlings, resulted in a common trend of height reduction. This ananicant effect is possibly due to nutrients saturation (Cruz et al., 2006) or accumulation of nossive salt levels (Mudita et al., 2014) which may lead to high levels of electric conductivity (Bezerra et al., 2017) and subsequent impact on plant growth by disturbing its physiological processes such as the apical meristems and leaf primordia emission. From our analysis, the level of salts observed in T9 raised form $0.05 \mathrm{mS} . \mathrm{cm}^{-}$up to $3.4 \mathrm{mS} . \mathrm{cm}^{-}$in the irrigation water collected in the present test, which also contain some fertilizers dropped from leaves during irrigation process. Studies regarding the electrical conductivity effect on cashew seedlings indicate negative relationships (Viegas et al., 2004).

\section{Concluding Remarks}

Two trials were conducted to determine the effect of different rates of cashew nut seedling fertilization on stem diameter and height. The diameter was linearly increased by increasing the rate of fertilizer regardless of being organic and thus incorporated in the soil or foliar sprayed on the leaves surface. The seedling stem height was linearly reduced by increased levels of fertilizer. Therefore fertilization can be used to adjust the stem size to the scions size available nearby the nursery. 


\section{Acknowledgements}

The authors acknowledge the Instituto de Amêndoas de Moçambique, IP for the financial support.

\section{References}

Aguiar, M. I., Lourenço, I. P., Oliveira, T. S., \& Lacerda, N. B. (2006). Perda de nutrientes por lixiviação em um Argissolo Acinzentado cultivado com meloeiro. Revista Brasileira de $\begin{array}{llll}\text { Eng. Agrícola } & e & \text { Ambiental } & \text { 10(4), }\end{array}$ https://doi.org/10.1590/S1415-43662006000400005

Akanbi, O. S. O., Famaye, A. O., Ojeniyi, S. O., Nduka, B. A., Taiwo, N., Olasupo, F. O., ... Gbemisola, D. O. (2013). Growth response of cashew seedlings to applied organic fertilizers of animal and plant origin on a degraded soil in Ibadan, South-West, Nigeria. Global Journal of Agricultural Sciences, 1(1), 95-100.

Almeida, E. I. B., Corrêa, M. C. M., Nóbrega, G. N., Pinheiro, E. A. R. and Lima, F. F. (2012). Crescimento e marcha de absorção de macronutrientes para a cultivar de melancia Crimson Sweet. Revista Agro Ambiente, 6(3), 205-214. https://doi.org/10.18227/1982-8470ragro.v6i3.778

Awodun M. A., Osundare O. T., Oyelekan S. A., \& Okonji C. J. (2015). Comparative effects of organic and inorganic soil amendments on the growth of cashew nut (Anacardium occidentale L.) seedlings. Journal of Agricultural Biotechnology and Sustainable Development, 7(4), 37-42. https://doi.org/10.5897/JABSD2015.0239

Banzatto, D. A., \& Kronka, S.N. (2006). Experimentação Agrícola - São Paulo, $4^{a}$ Edição

Bezerra, I. L., Nobre, R. G., Gurgel, M. T.,Gheyi, H. R., \& Gernandes, P. D. (2017). Índices fisiológicos e de crescimento de porta-enxertos de cajueiro anão precoce sob estresse salino. Rev. Espacios, 38(2), 4.

Bhardwaj, D., Ansari, M. W., Sahoo, R. K., \& Tuteja, N. (2014). Biofertilizers function as key player in sustainable agriculture by improving soil fertility, plant tolerance and crop productivity. Microbial CellFactories, 13(66). https://doi.org/10.1186/1475-2859-13-66

Caldeira, M. V. W., Schumacher, M. V., Oliveira, E. R. V., Luciano, E. L.s P., \& Watzlawick, F. (2003). Influência de Vermicomposto na Produção de mudas de Pinu selliottii Engelm. Revista Ciências Agrárias e Ambientais, Curitiba, 1(3), 47-53. https://doi.org/10.7213/cienciaanimal.v1i3.14943

Cavalcanti Jr, A.T., \& Chaves, J.C.M., (2001). Produção de mudas de cajueiro. Fortaleza: Embrapa Agro-Indústria Tropical. 43p.

Clement, C. R., \& Bovi, M. L. A. (2000). Padron ização de medidas de crescimento e produção em experimentos com pupunheira para palmito. Acta amazonia, 30(3), 349-362. https://doi.org/10.1590/1809-43922000303362

Correia, D., Rosa, M. F., Norões, E. R. V., \& De Araújo, F. B. (2003). Uso do Pó da Casca de 
Coco na Formulação de Substratos para formação de Mudas Enxertadas de Cajueiro Anão Precoce. Rev. Bras. Frutic., Jaboticabal - SP, 25(3), 557-558. https://doi.org/10.1590/S0100-29452003000300052

Costa, E., Durante, L. G. Y., Nagel, P. L., Ferreira, C. R., \& Santos, A. (2011). Qualidade de mudas de berinjela submetida a diferentes métodos de produção. Rev. Ciênc. Agron., 42(4), 1017-1025. https://doi.org/10.1590/S1806-66902011000400026

Cruz, J. L, Pelacani, C. R., \& Araújo, W. L. (2006). Efeito do nitrato e amonia sobre o crescimento e eficiência de utilização do nitragenio em mandioca. Bragantia, Campinas, 65(3), 467-475. https://doi.org/10.1590/S0006-87052006000300013

De Lima, R. L. S., Fernandes, V. L. B., Oliveiras, V. H., \& Hernandez, F. F. F.(2001). Crescimento de mudas de cajueiro-anão-precoce CCP-76 submetidas à adubação organica e mineral. Ver. Bras. Frutc., Jaboticabal-SP, 23(2), 391-395. https://doi.org/10.1590/S0100-29452001000200039

Dendena, B., \& Corsi, S. (2014). Cashew From Seed to Market. A review Agron. Sustain. Dev., 34, 753-772; https://doi.org/10.1007/s13593-014-0240-7

Dias, L. A. dos S., \& Barros, W. S. (2009). Biometria Experimental. LAS Dias \& W.S. Barros. Brasil. 408p.

Dixit, S. (2011). Impact of Bio-fertilization on Morphological Parameters of Vigna mungo (L.) Hepper. Int. Jour. Res. in Plant Science, 3(1), 10-13.

Eloy, E., Caron, B. O., Schmidt, D., Behling, A., Schwers, L., \& Elli, E. F. (2013). Avaliação da Qualidade de Mudas de Eucalyptusgrandis utilizando Parâmetros Morfológicos. Rev. FLORESTA, Curitiba, PR, 43(3), 373-384. https://doi.org/10.5380/rf.v43i3.26809

Fonseca, E. P., Valéri, S. V., Miglioranza, E., Fonseca, N. A. N., \& Couto, L. (2002). Padrão de Qualidade de Mudas de Trema micrantha (L.) Blume, Produzidas sob Diferentes Períodos de Sombreamento. Rev. Árvore, Viçosa-MG, 26(4), 515-523. https://doi.org/10.1590/S0100-67622002000400015

Frei, V. V. M. (2013). A produção de Caju e a Dinâmica Sócio-Espacial no Distrito de Angoche, Nampula-Moçambique - p.208.

Gomes, J. M., Couto, L., Leite, H. G., Xavier, A., \& Garcia, S. L. R. (2003) Crescimento de mudas de Eucalyptus grandis em diferentes tamanhos de tubetes e fertilização NPK. Revista Árvore, 27(2), 113-127. https://doi.org/10.1590/S0100-67622003000200001

Gomez, A. K., \& Gomez, A. A. (1984). Statistical Procedures for Agricultural Research, $2^{\text {nd }}$ Edition. John Wiley \& Sons Inc. Canada.

Grobe-Rüschkamp, A. G., \& Seelige, K. (2010). Análise da Cadeia de Valor do Caju em Moçambique. Iniciativa Africana do Caju, Acra e Maputo: Deutsche Gesellschaft für Internationale Zusammenarbeit (GIZ).

Low, J., de Marrule, H., Boughton, D., \& Pitoro, R. (2001) A regulamentação de 
comercialização da castanha de caju: Como torná-la um instrumento revitalizador do subsector cajueiro em Moçambique? Flash N. 25P. Maputo: Ministério da Agricultura e Desenvolvimento Rural.

Mário, L. M. V., Danila, L. A., Gilmar, G. S., José, S. M. F., \& Raimundo, A. (2014). Efeito do biofertilizante e de volumes de substrato no desenvolvimento de mudas de caju; Revista Verde (Pombal - PB), 9(2), 325-332.

Martin , P. J., Topper, C. P., Bashiru, R. A., Boma, F., De Waal, D., Harries, H. C., ... Sijaona, T. (1997). CashewNutProductioninTanzania: Constraintsand progress through integrated crop management - Mtwara, Tanzania - L evierScienceLtd, P10. https://doi.org/10.1016/S0261-2194(96)00067-1

Melo Filho, J. S., Araújo, D. L., Véras, M. L. M., Irineu, T. H. S., \& Andrade, R. (2015). Produção de Mudas de Caju (AnacardiumOccidentale L.) Sob aplicação de biofertilizante em dois volumes de Substratos. Terceiro Incluído Issn 2237-079 x Nupeat-Iesa-Ufg, 5(2), 65-74. https://doi.org/10.5216/teri.v5i2.38735

Milheiro, A. V., \& Evaristo, F. N. (1994). Manual do Cajueiro. Associação de técnicas de culturas tropicais, $1^{\text {a }}$ edição, Porto-Portugal.

Mostafa, G. G., \&Abo-Baker, A. A. (2010). Effect of Bio and Chemical Fertilization on Growth of Sunflower (Helianthus annuus L.) at South Valley Area. Asian J. Crop Sci., 2(3), 137-146. https://doi.org/10.3923/ajcs.2010.137.146

Mudita, I. I.,Chipfiko, P., Mapfumo, P., \& Tigere, T. A., (2014). Effects of Foliar Fertilizer on Yield and Quality of Green Mealies (Zea mays L.) Jorn. Agron., 13(1), 35-39. https://doi.org/10.3923/ja.2014.35.39

Pes, L. Z., \& Arenhardt, M. H. (2015). Fisiologia Vegetal. Santa Maria, RS: Universidade Federal de Santa Maria, Colégio Politécnico, Rede e-Tec Brasil; 2; 81p.

Petersen, R.G. (1994). Agricultural field experiments. Design and Analysis. Marcel Dekker Inc. New York. 409pp.

Prado, R. M., \& Leal, R. M. (2006). Desordens nutricionais por deficiência em girassol, var. Catissol. Pesquisa Agropecuária Tropical, 36(3), 187-193.

Ricau, P. (2019). The West African cashew sector in 2018. General trends and country profiles. Analysis of cashew production, processing and tred in West Africa. Nitidae. https://www.nitidae.org/files/41dc7432/wa_cashew_sector_review_2019_nitidae.pdf

Rickli, L., \& Peres, F. S. B. (2016). Uso de biofertilizantes à base de aminoácidos na produção de mudas de Eucalyptus dunnii. Pesq. flor. bras., Colombo, 36(87), 211-218. https://doi.org/10.4336/2016.pfb.36.87.1127

Rossiello, R. O. P., Araújo, C. V. M., \& Fernandes, M. S. (1995). Comparação dos Métodos Fotoeléctricos e da Intersecção na Determinação de Área, Comprimento e Raio Médio Radicular. Pesq. Agropec. Bras., Brasília, 30(5), 633-638. 
Roy, R. N., Finck, A., Blair, G. J., \& Tandon, H. L. S. (2006). Plant Nutrition for Food Security. A guide for integrated nutrient management - Viale delle Terme di Caracalla, 00100 Rome, Italy - FAO, 366p.

Salustiano, V., Achicala, R., Lampeão, S., Lopes, L.S., Mabota, A., Matlombe, H., ... Diogo, D. (2015). Anuário de Estatísticas Agrárias 2012-2014., Ministério da Agricultura e Segurança Alimentar. Maputo.

Schmildt, E. R., Oliari, L. S.,Schmildt, O., Alexandre, R. S., \& Pires, F. R. (2016). Determinação da área foliar de Passiflora mucronata a partir de dimensões lineares do limbo foliar. Revista Agro-ambiente On-line, 10(4), 351-357. https://doi.org/10.18227/1982-8470ragro.v10i4.3720

Serrano, L. A. L, Melo, D. S., Martins, T. S., Taniguchi, C. A. K., \& Hawerroth, F. J. (2018). Produção de mudas de cajueiro 'CCP 76' em diferentes substratos e doses de adubo de liberação lenta (NPK 16-08-12). Boletim de pesquisa e desenvolvimento 184/ Embrapa Agroindústria Tropical, ISSN 1679-6543; 184, 1-23.

Serrano, L. A. L., \& Cavalcanti Júnior, A. T. (2016). Sistemas de produção de caju - Embrapa Agroindústria Tropical, Vol. 1, $2^{a}$ edição. Disponível em: https://www.spo.cnptia.embrapa.br

Shankarappa, T. H., Mushrif, S. K., Subramanyam, B., Sreenatha, A., Prasad, M. B. N., \& Reddy, N. A. (2017). Effect of Biofertilizers on Growth and Establishment of Cashew Grafts under Nursery Condition. Int. Jour. Curr. Microbiol.App. Sci., 6(8), 1959-1965. https://doi.org/10.20546/ijcmas.2017.608.232

Shehata, M. M., \& El-Khawas, S. A. (2003). Effect of two biofertilizers on growth parameters, yield characters, nitrogenous components, nucleic acids contents, minerals, oil content, protein profiles and DNA banding pattern of sunflower (Helianthus annus. L.cv. vedock) yield. Pak. J. Biol. Sci., 6, 1257-1268. https://doi.org/10.3923/pjbs.2003.1257.1268

Sijaona, M. E. R. \& Mansfieid, J. W. (1999). Structural Resistance of Cashew (Anacardium occidentale) against Powdery Mildew (Oidium anacardii). Tanzania Jour. Agric. Sc. 2(1), 115-125.

Silva, E.M., Parreira, M. C.i, Siebeichler, S. C., Santos, E. R., Souza, C. M., Neto, F. C. V., \& Freitas, G. A. (2019). Produção de mudas de cajueiro anão-precoce em substratos de resíduos orgânico. Revista Brasileira de Agropecuária Sustentável (RBAS), 9(1), 90-96, https://doi.org/10.21206/rbas.v9i1.7969

Torres, E. C. M., Freire, J. L. O., Oliveira, J. L., Bandeira, L. B., Melo, D. A., \& Silva, A. L. (2014). Biometria de mudas de cajueiro anão irrigadas com águas salinas e uso de

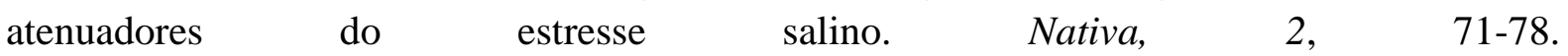
https://doi.org/10.14583/2318-7670.v02n02a03

Viégas, R. A., Silveira, J. A. G., Silva, L. M. M., Viégas, P. R. A., Queiroz, J. E., \& Rocha, I. M. A. (2004). Redução assimilatória de nitrato em cajueiros cultivados em meio salinizado. Rev. Bras. Eng. Agricola Ambiental, Campina Grande, 8(2/3), 
189-195. https://doi.org/10.1590/S1415-43662004000200005

Walker, E. (2009). Estudo da Viabilidade Económica na Utilização de Biomassa como Fonte de Energia Renovável na Produção de Biogás em Propriedades Rurais - Universidade Regional do Noroeste do Estado do Rio Grande do Sul - UNIJUÍ.

\section{Copyright Disclaimer}

Copyright for this article is retained by the author(s), with first publication rights granted to the journal.

This is an open-access article distributed under the terms and conditions of the Creative Commons Attribution license (http://creativecommons.org/licenses/by/4.0/). 